\title{
Comparative Evaluation of Trace Heavy Metal Ions in Water Sample Using Complexes of Dithioligands by Flame Atomic Absorption Spectrometry
}

\author{
VINAY KUMAR MAURYA, RAVI PRATAP SINGH and LAL BAHADUR PRASAD*
}

Department of Chemistry, Institute of Science, Banaras Hindu University, Varanasi- 221005, India.

*Corresponding author E-mail: Ibprasad@bhu.ac.in

http://dx.doi.org/10.13005/ojc/340111

(Received: November 03, 2017; Accepted: December 15, 2017)

\section{ABSTRACT}

Four new complexes were prepared by the metathetic reaction of trace heavy metals like $\mathrm{Cd}, \mathrm{Zn}, \mathrm{Cu}$ and $\mathrm{Hg}$ with two different dithioligands of the formula $\mathrm{ML}_{2}[\mathrm{M}=\mathrm{Cd}, \mathrm{Zn}, \mathrm{Cu}$ and $\mathrm{Hg}$ and $\mathrm{L}=$ potassium-1,1-dicyano-2,2-ethylenedithiolate and potassium $\mathrm{N}$-4-fluorobenzyl, $\mathrm{N}$ butyldithiocarbamate ] and characterized by elemental analysis, IR, UV-visible, ${ }^{1} \mathrm{H},{ }^{13} \mathrm{C}$ NMR and AAS. Atomic Absorption Spectrophotometric measurements revealed that the $\mathrm{N}$ - substituted dithiocarbamate ligand are more effective. Removal efficiency of heavy metals than carbon substituted dithiocarbamate ligand. Molar ratio studies show that the complexes have the formula $\mathrm{ML}_{2}$. Solvent extraction measurement indicates that after the extraction of heavy metal in water phase and their dithiocarbamate complexes are completely dissolved in organic phase and are totally separated from aqueous solution.

Keywords: Atomic Absorption Spectrometry, Dithiocarbamate, Heavy Metal, Removal Efficiency, Polluted Water.

\section{INTRODUCTION}

Dithiocarbamate functional group is a versatile ligating moiety and readily interacts with a verity of metal ions to form complexes with varying nuclearities ${ }^{1}$. They have wide range of application in medicinal chemistry, industrial chemistry, rubber technology $y^{2-6}$ and several carbon substituted and $\mathrm{N}$-substituted dithiocarbamate complexes used in agrochemicals due to their high efficiency for fungal diseases $^{7-10}$ and adopt various coordination modes such as asymmetric and symmetric chelating, bridging and rarely monodentate in their complexes, the most common binding mode is chelating. The dithiocarbamate ligands show ability to stabilized high formal oxidation states of the metals and metal dithiocomplexes exhibits interesting magnetic and optical properties ${ }^{11-12}$.

This is an Open Access article licensed under a Creative Commons Attribution-NonCommercial-ShareAlike 4.0 International License (https://creativecommons.org/licenses/by-nc-sa/4.0/ ), which permits unrestricted NonCommercial use, distribution and reproduction in any medium, provided the original work is properly cited. 
Heavy metals are high atomic weight elements and their density about five times greater than water. Toxicity of heavy metals depends upon the doses of individuals, ways of unveiling and their chemical species, as well as age, gender, genetics and nutritional states of unveiling individuals. Environmental water pollution through toxic heavy metals has great anxiety and a dangerous problem due to the liberation and prejudicial effects. These metals found through anthropogenic activities ${ }^{13}$ and liberated into the atmosphere, and they destroy the metabolic function by their accumulation and disturb the function of vital organs and glands such as heart, brain, kidney, bone, liver etc. and or plants ${ }^{14}$. By the consumption of food, beverages, skin exposure and the inhaled air these toxins, have been introduced into our bodies.

In this article we have chosen pollutants like cadmium, zinc, copper and mercury. These metals have wide applications in applied engineering works, pulp and paper industries, leather tanning, plastic stabilizers, pigments, photographic materials, fertilizers, batteries etc. Additionally, cadmium and lead are known as toxical effects and have a harmful impact on the humans health and living organisms ${ }^{15}$. Zinc and copper are comparatively non-toxic to humans and animals at low level but toxic to plants and algae at higher level while cadmium replace zinc biochemically ${ }^{16}$, causes high blood pressure, kidney damage and red blood cells and mercury is a highly toxic particularly as methylmercury, causes irreversible nerves and brain damage. Many methods have been adopt for the separation of heavy metals from various water sample before being discharged into the atmosphere but in some cases difficulties are arises in determining the heavy metals in the environmental samples due to scanty sensitivity and or matrix interferences ${ }^{17-18}$.

Therefore, a new approach of separation and enrichment for heavy metals ions and determination by AAS was undertaken here. It is used as usual instrumental techniques for the analysis of element in water samples. It is a very sensitive technique and have very low interference ${ }^{19-20}$, and detect element up to few ppm level when graphite furnace is used for the atomization. The selection of more appropriate treatment for the metal- contaminated polluted water depends on initial parameters like $\mathrm{pH}$, initial metal concentration and the overall treatment performance. In this study two different moiety of dithiocarbamate ligands ( $\mathrm{N}$ substituted \& C- substituted) were prepared and compared their performance for the removal efficiency of heavy metal from the water sample with the help of flame atomic absorption spectrometer.

\section{MATERIALS AND METHODS}

All the experiment were carried out in the open atmosphere at room temperature. The solvent were dried and distilled before use following the standard procedure. The chemicals Malononitrile, 4-Fluorobenzaldehyde, Butyl amine, $\mathrm{NaBH}_{4}, \mathrm{CS}_{2}$, Dioxane, Dichloromethane, and $\mathrm{KOH}$ (E.Merck) were used as received.

\section{Instrumentation}

The concentrations of $\mathrm{Cd}, \mathrm{Zn}, \mathrm{Cu}$ and $\mathrm{Hg}$ were determined using a ALICO SL -168 Model Flame Atomic Absorption Spectrometry (FAAS) equipped with a hollow cathode lamp. A mixture of acetylene as a fuel, air as an oxidizing agent and air acetylene Flame burner were used. The ratio of the metal to the ligand was determined using a UVSpectrophotometer (SHIMADZU 1700). For $\mathrm{pH}$ adjustment, we used a Metrohm pH Meter. The melting points of the ligands and complexes were recorded by digital melting point apparatus in open capillary. Infrared spectra were carry out as $\mathrm{KBr}$ Pellets on a Varian Excallibur $3100 \mathrm{FT}-\mathrm{IR}$ Spectrophotometer in the range of $4000-400 \mathrm{~cm}^{-1}$. The contents of $\mathrm{C}, \mathrm{H}, \mathrm{N}$, were determined with the help of an Elementar Analysen System Gmbh Vario EL V 3.00 instruments.

\section{Preparation of ligands \\ Preparation of potassium-1,1-dicyano-2,2- ethylenedithiolate $\left(\mathrm{KL}_{1}\right)$}

The ligand $K L_{1}$ was synthesized by the reported method with some minor modification ${ }^{21}$. To a suspension of pulverized $\mathrm{KOH}(11.2 \mathrm{~g}, 0.2 \mathrm{~mol})$ in dioxane, a mixture of carbon disulphide $(6.3 \mathrm{ml}, 0.1$ $\mathrm{mol}$ ) and malononitrile $(6.1 \mathrm{ml}, 0.1 \mathrm{~mol})$ in the same solvent $(50.00 \mathrm{ml})$ was added gradually with constant stirring. The temperature of the reaction mixture was maintained at bellow $15{ }^{\circ} \mathrm{C}$ using an ice bath in order to inhibit any possible 
decomposition of the product due to nature of the reaction is exothermic. The reaction mixture was stirred for about $30 \mathrm{~min}$. after the complete addition of the reactants and after some time it was diluted with $250 \mathrm{ml}$ of the diethyl ether. The yellowish precipitate was formed out and it was suction filtered, washed with mixture of dioxane - ether and dried in vacuum.

\section{Analysis}

Found (calcd.) \% for $\mathrm{C}_{4} \mathrm{~N}_{2} \mathrm{~S}_{2} \mathrm{~K}_{2} \cdot \mathrm{H}_{2} \mathrm{O}: \mathrm{C}$, 20.28(20.34); N, 11.84(11.86); S, 26.45(27.12); H, 1.06(0.95)<smiles>N#CC[C+]=[Po]</smiles><smiles>N#CC(C#N)=C([Se])[Se]</smiles>

Malononitrile

\section{(Scheme A)}

Preparation of potassium N-4-fluorobenzyl,Nbutyldithiocarbamate $\left(\mathrm{KL}_{2}\right)$

The $\mathrm{KL}_{2}$ ligand was prepared from secondary amine, obtain by reduction of Schiff base , which was prepared ${ }^{22-23}$ by using the 4-fluorobenzaldehyde (12.4 g, $0.1 \mathrm{~mol}$ ) and butyl amine $(7.30 \mathrm{~g}, 0.1 \mathrm{~mol})$ and dissolved in $25 \mathrm{~mL}$ ethyl alcohal and refluxed on paraffin oil bath for 8 hours and reducing it by the mixture was kept on ice bath, stirred well and then $\mathrm{NaBH}_{4}$ and methanol were added, the secondary amine produce, then it was extracted with $50 \mathrm{ml} \mathrm{CH}_{2} \mathrm{Cl}_{2}$ solution and washed with $45 \mathrm{ml}$ distilled water three times. The oily yellow to light pink product was collected on solvent removal. The dithiocarbamate ligand were synthesizedby the reaction of the secondary amines prepared earlier and dissolved in $15 \mathrm{~mL}$ THF, $\mathrm{KOH}$ (5.60 g,0.1 mol) and add $\mathrm{CS}_{2}(7.60 \mathrm{~g}, 0.1 \mathrm{~mol})$ drop wise with constant stirring under temperature bellow $10^{\circ} \mathrm{C}$. The yellow precipitate was formed which was again stirring about $4 \mathrm{~h}$ and filtered it. The residue washed with 2-3 times of diethyl ether and dried.

\section{Analysis}

Found (Calcd.) \% for $\mathrm{C}_{12} \mathrm{H}_{15} \mathrm{FNS}_{2} \mathrm{~K}: \mathrm{C}$, 48.78(48.84); N, 4.74(4.78); S, 21.70(21.78); H, $5.12(5.18)$

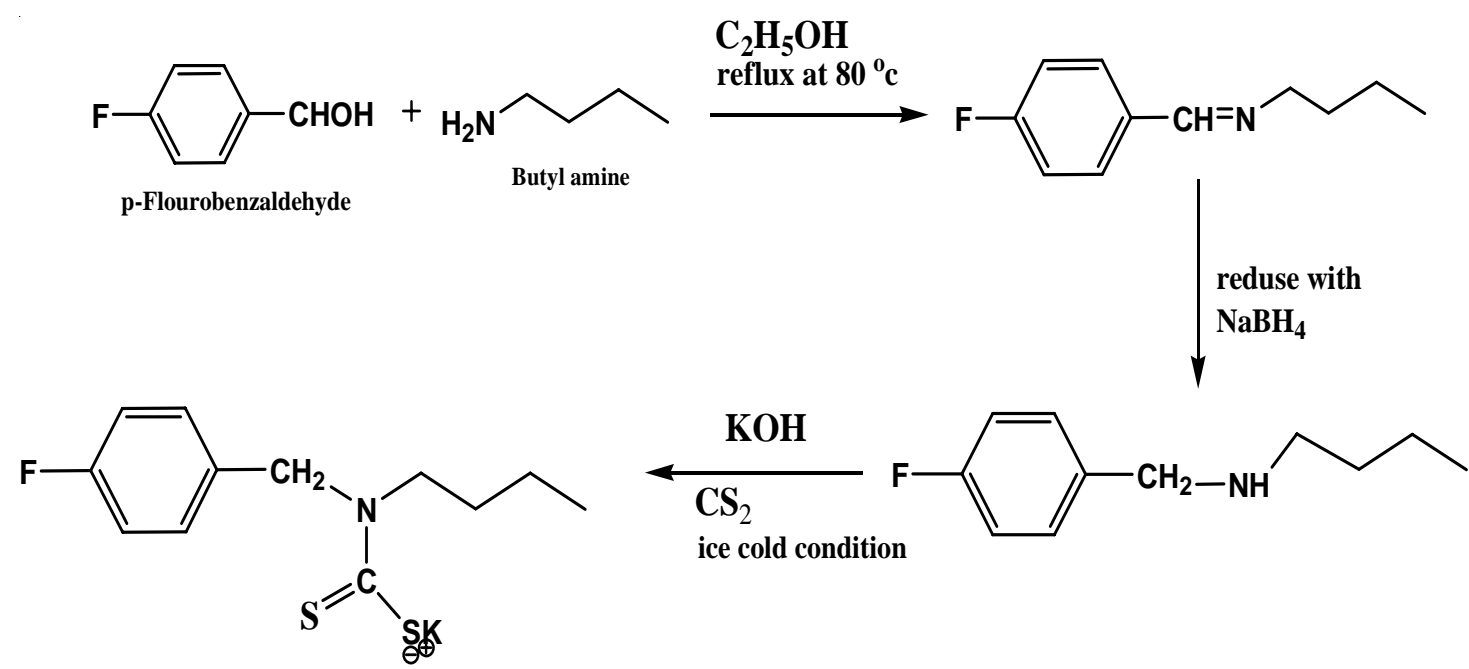

(Scheme B) 
Synthesis of the complexes of heavy metal with $\left(\mathrm{KL}_{1}\right)$ and $\left(\mathrm{KL}_{2}\right)$ Ligands

The complexes were prepared by taking $20 \mathrm{~mL}$ methanolic solution of the ligands KL1 (0.218 $\mathrm{g}, 1 \mathrm{mmol})$ and $\mathrm{KL}_{2}(0.295 \mathrm{~g}, 1 \mathrm{mmol})$ and $20 \mathrm{~mL}$ methanol: water $(80: 20)$ solution of $\mathrm{M}\left(\mathrm{OOCCH}_{3}\right)_{2}$. $2 \mathrm{H}_{2} \mathrm{O}$ ( $\left.0.5 \mathrm{mmol}\right)[\mathrm{M}=\mathrm{Cd}, \mathrm{Zn}, \mathrm{Cu}$ and $\mathrm{Hg}]$ in $2: 1$ molar ratio ${ }^{22-23}$. All the reaction mixture was stirred for $6 \mathrm{~h}$ at room temperature for the precipitation of metal-complexes. The precipitate obtain was filtered and washed with methanol followed by diethyl ether and analyzed by different spectroscopic techniques. The elemental analysis data and \% yield of the prepared complexes are shown in Table 1 and 2.

Table. 1: The elemental analysis (\%) and the yield (\%) of complex formation for ligand $\mathrm{KL}_{1}$

\begin{tabular}{lcccccc}
\hline S.No. & Complexes & $\mathrm{C} \%$ & $\mathrm{~N} \%$ & $\mathrm{~S} \%$ & Metal \% & Yield (\%) \\
\hline 1 & {$\left[\mathrm{Cd}\left(\mathrm{C}_{4} \mathrm{~N}_{2} \mathrm{~S}_{2}\right)_{2}\right]$} & $28.58(28.34)$ & $16.66(15.96)$ & $38.15(37.12)$ & $16.61(15.89)$ & 98.72 \\
2 & {$\left[\mathrm{Zn}\left(\mathrm{C}_{4} \mathrm{~N}_{2} \mathrm{~S}_{2}\right)_{2}\right]$} & $27.94(27.12)$ & $16.29(16.02)$ & $37.29(37.16)$ & $18.48(18.32)$ & 99.01 \\
3 & {$\left[\mathrm{Cu}\left(\mathrm{C}_{4} \mathrm{~N}_{2} \mathrm{~S}_{2}\right)_{2}\right]$} & $27.79(27.47)$ & $16.20(15.98)$ & $37.09(36.86)$ & $18.91(18.48)$ & 99.18 \\
4 & {$\left[\mathrm{Hg}\left(\mathrm{C}_{4} \mathrm{~N}_{2} \mathrm{~S}_{2}\right)_{2}\right]$} & $24.75(24.23)$ & $14.43(14.03)$ & $33.04(32.82)$ & $27.78(27.32)$ & 98.79 \\
\hline
\end{tabular}

Table. 2: The elemental analysis (\%) and the yield (\%) of complex formation for ligand $\mathrm{KL}_{2}$

\begin{tabular}{|c|c|c|c|c|c|c|c|}
\hline S.No. & Complexes & $\mathrm{C} \%$ & $\mathrm{H} \%$ & $\mathrm{~N} \%$ & $\mathrm{~S} \%$ & Metal \% Y & Yield (\%) \\
\hline 1 & {$\left[\mathrm{Cd}\left(\mathrm{C}_{12} \mathrm{H}_{15} \mathrm{NFS}_{2}\right)_{2}\right]$} & $50.69(50.46)$ & $5.32(5.11)$ & $4.93(4.86)$ & $22.56(22.12)$ & $9.82(9.78)$ & 98.88 \\
\hline 2 & {$\left[\mathrm{Zn}\left(\mathrm{C}_{12} \mathrm{H}_{15} \mathrm{NFS}_{2}\right)_{2}\right]$} & $50.02(49.89)$ & $5.25(5.13)$ & $4.86(4.78)$ & $22.26(22.16)$ & $11.03(10.92)$ & 99.09 \\
\hline 3 & {$\left[\mathrm{Cu}\left(\mathrm{C}_{12} \mathrm{H}_{15} \mathrm{NFS}_{2}\right)_{2}\right]$} & $49.86(49.78)$ & $5.23(5.16)$ & $4.85(4.73)$ & $22.18(22.07)$ & $11.31(11.24)$ & 99.21 \\
\hline 4 & {$\left[\mathrm{Hg}\left(\mathrm{C}_{12} \mathrm{H}_{15} \mathrm{NFS}_{2}\right)_{2}\right]$} & $46.45(46.13)$ & $4.87(4.39)$ & $4.51(4.42)$ & $20.67(20.51)$ & $17.38(17.22)$ & 98.93 \\
\hline
\end{tabular}

\section{RESULTS AND DISCUSSION}

\section{Infrared spectra}

The ligands $\left(\mathrm{KL}_{1}\right.$ and $\left.\mathrm{KL}_{2}\right)$ act as a bidentate ligand. The $\left(\mathrm{KL}_{1}\right)$ ligand can be represented in three forms as shown under

The ligand $\left(\mathrm{KL}_{1}\right)$ and all the complexes shows IR absorption near $2000 \mathrm{~cm}^{-1}, 1400 \mathrm{~cm}^{-1}$ and $950 \mathrm{~cm}^{-1}$ associated to $\vartheta(\mathrm{C} \equiv \mathrm{N}), \vartheta(\mathrm{C}=\mathrm{C})$ and $\vartheta(\mathrm{C}-\mathrm{S})$ mode respectively ${ }^{26-27}$. The two most important feature of the spectra are the shift $12-30 \mathrm{~cm}^{-1}$ in $\vartheta(\mathrm{C} \equiv \mathrm{N})$ and $15-21 \mathrm{~cm}^{-1}$ in $\vartheta(\mathrm{C}=\mathrm{C})$ from the ligand $\left(\mathrm{KL}_{1}\right)$ spectra to that of the complexes. In ligand spectra, two bands $\vartheta(\mathrm{C} \equiv \mathrm{N})$ and $\vartheta(\mathrm{C}=\mathrm{C})$ are located near at $2178 \mathrm{~cm}^{-1}$ (split band) and $1375 \mathrm{~cm}^{-1}$ respectively. Upon complexation these bands are observed in $2190-2207 \mathrm{~cm}^{-1}$ and $1383-1395 \mathrm{~cm}^{-1}$ region in all the complexes.

The splitting in $\vartheta(\mathrm{C} \equiv \mathrm{N})$ observes in the most of the complexes may be related to the lower symmetry for these complexes. This may be indicative of bidentate bridging behavior of $\left(\mathrm{KL}_{1}\right)$ ligand. The $\vartheta(C-S)$ vibration occurring at $950 \mathrm{~cm}^{-1}$ and $874 \mathrm{~cm}^{-1}$ in $\left(\mathrm{KL}_{1}\right)$ is observed in 866-950 $\mathrm{cm}^{-1}$ region in the complexes thereby indicating coordinating behavior of isomaleonitriledithiolate ligand.

The ligand $\left(\mathrm{KL}_{2}\right)$ and all the complexes showed the IR absorption near $2926 \mathrm{~cm}^{-1}, 1206$ $\mathrm{cm}^{-1}, 1149 \mathrm{~cm}^{-1}$ and $994 \mathrm{~cm}^{-1}$ associated to $\vartheta(\mathrm{CH} 3)$, $\vartheta(\mathrm{C}-\mathrm{N}), \vartheta(\mathrm{C}=\mathrm{S})$ and $\vartheta(\mathrm{C}-\mathrm{S})$ mode respectively. Upon complexation these bands are shifted $14-19 \mathrm{~cm}^{-1}$ in

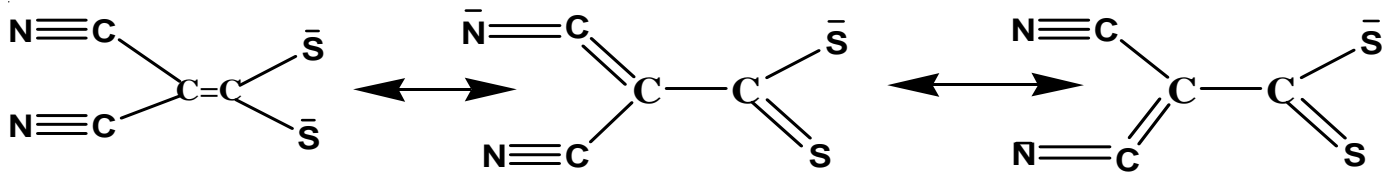


$\vartheta(\mathrm{C}=\mathrm{S}), 6-12 \mathrm{~cm}^{-1}$ in $\vartheta(\mathrm{C}-\mathrm{S})$ and $11-18 \mathrm{~cm}^{-1}$ in $\vartheta(\mathrm{C}-\mathrm{N})$ in all the complexes ${ }^{23}$.

\section{Yoe-Jones Method for the Determination of} Stoichiometry of complexes

In this studies, a set of series of sample solution were prepared in which the concentration of one reactant is kept as constant and other is different. The absorbance of each solution is determined and plot a graph between absorbance and the concentration of the ligand. For example we take zinc metal and their concentration fixed at $5 \mathrm{pp}$ min. a solution at $\mathrm{pH} 7$ considered as blank sample. Then the absorbance of the sample to be determines containing the metal plus the ligand at concentration i.e. 1, 2, 4, 6, 8, 10, 12, 15, 20 and 25 ppm respectively. By the extrapolating the graph, the intercept of plot becomes $10 \mathrm{ppm}$, this is the double concentration of the metal, suggesting that a complex have formula $\mathrm{ML}_{2}^{24-25}$. This method was repeated for each metals with both ligands. A representative example are shown in Figure. 1 and 2.

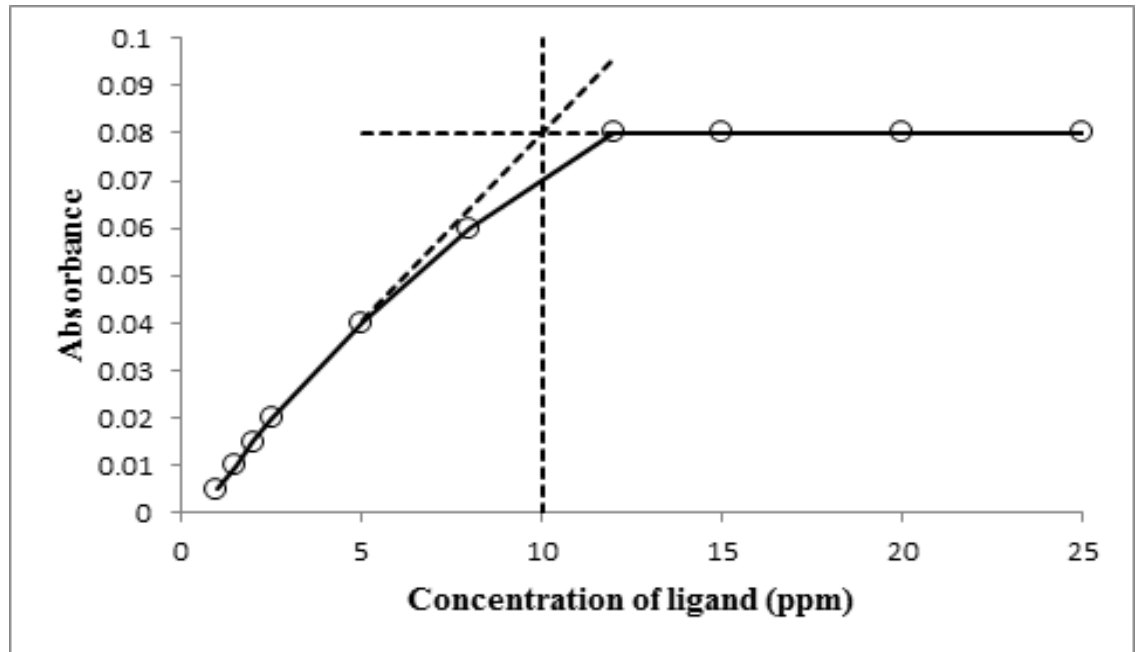

Fig. 1. Determination the of $\mathrm{Zn}$ ratio to $\left(\mathrm{KL}_{1}\right)$ ligand

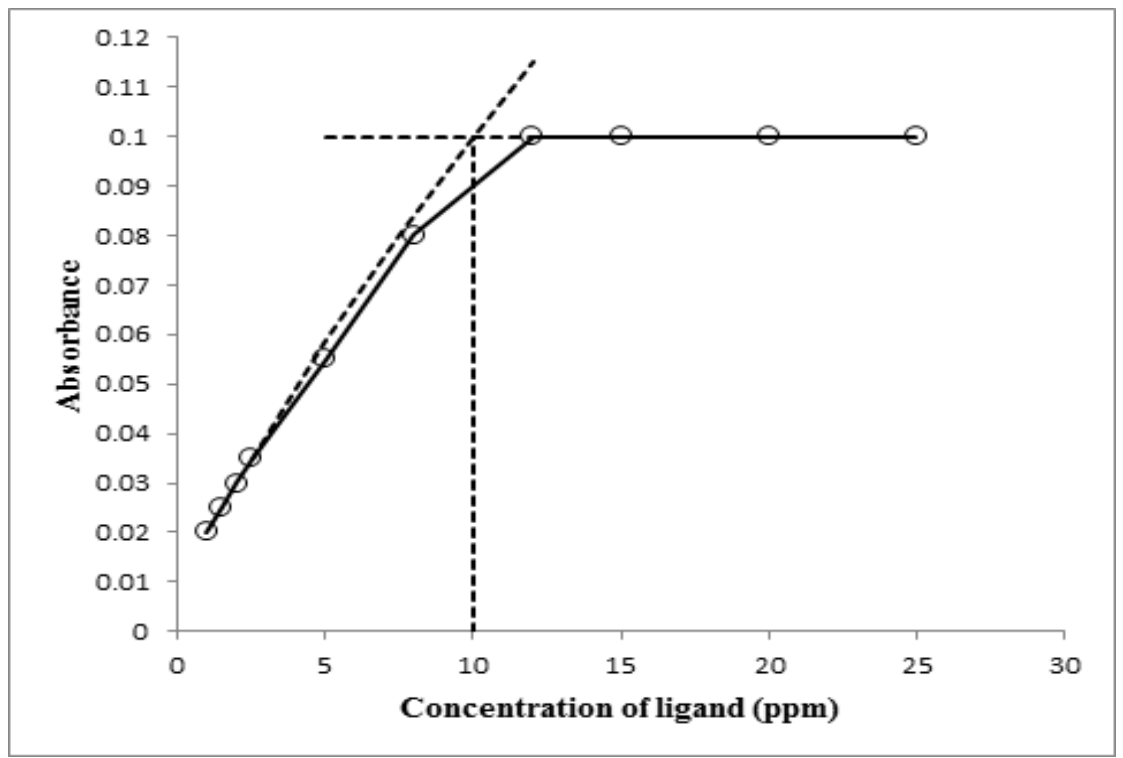

Fig. 2. Determination of $\mathrm{Zn}$ ratio to $\left(\mathrm{KL}_{2}\right)$ ligand 
The Solvent extraction of the heavy metal dithiocarbamate

$0.1 \%$ of known amount of ligands was taken in R.B. and $0.05 \mathrm{mg} / \mathrm{L}$ and $5 \mathrm{mg} / \mathrm{L}$ water standered solution of heavy metal ions was added and stirred for $30 \mathrm{~min}$. at room temperature. Similarly the metal complexes were extracted with $10 \mathrm{ml}$ of dichloromethane solution. The heavy metal absorbance in water phase was determined by atomic absorption spectrometry (flame system and furnace system) at different $\mathrm{pH}$ (3-11) after removing the organic phase of the solution and it was compared with the absorbance of initial solution of heavy metal ion $(0.05$ and $5.0 \mathrm{mg} / \mathrm{L} \mathrm{HM}$ standard solution). The $\mathrm{pH}$ of the solution was adjusted with $\mathrm{HCl}$ and $\mathrm{NaOH}$ or maintained by a suitable buffer at desired volume. Acetate buffer for $\mathrm{pH}$ 3-5, phosphate buffer of 6-8 and carbonate buffer for $\mathrm{pH}$
9-11. Our main aim for the extraction of heavy metal from water solution is to separate trace level of heavy metal ions from the solution. The heavy metal precipitateted as metal dithiocarbamate complex after using $10 \mathrm{ml}$ volume of the $\mathrm{CH}_{2} \mathrm{Cl}_{2}$ solution for the extraction. The absorbance of heavy metal ions $(0.050$ and $5.0 \mathrm{mg} / \mathrm{L})$ are measured before and after adding the dithiocarbamate solutions by the atomic absorption spectrometry. After the $\mathrm{CH}_{2} \mathrm{Cl}_{2}$ extraction shows that absorbance of trace heavy metal ions in the water phase is lower than the absorbance of initial concentration of trace heavy metal solution by the AAS measurement. This measurement demonstrate that after the extraction of heavy metal in water phase and their dithiocarbamate complexes are completely dissolved in organic phase and are totally separated from water solution.

Table. 3: Metal removal efficiency of KL1 ligand with $0.05 \mathrm{mg}$ metals

\begin{tabular}{|c|c|c|c|c|}
\hline Metal & $\begin{array}{l}\text { Initial concentration } \\
(\mathrm{ppm})\end{array}$ & $\begin{array}{l}\text { Remaining concentration in } \\
\text { aqueous solution (ppm) }\end{array}$ & $\mathrm{pH}$ & $\begin{array}{l}\text { Removal } \\
\text { efficiency (\%) }\end{array}$ \\
\hline \multirow[t]{5}{*}{$\mathrm{Cd}$} & 0.813 & 0.172 & 3 & 78.84 \\
\hline & & 0.168 & 5 & 79.33 \\
\hline & & 0.104 & 7 & 87.20 \\
\hline & & 0.123 & 9 & 84.87 \\
\hline & & 0.136 & 11 & 83.27 \\
\hline \multirow[t]{5}{*}{$\mathrm{Zn}$} & 0.941 & 0.197 & 3 & 79.06 \\
\hline & & 0.162 & 5 & 82.78 \\
\hline & & 0.148 & 7 & 84.27 \\
\hline & & 0.098 & 9 & 89.58 \\
\hline & & 0.129 & 11 & 86.29 \\
\hline \multirow[t]{5}{*}{$\mathrm{Cu}$} & 0.792 & 0.115 & 3 & 85.47 \\
\hline & & 0.107 & 5 & 86.48 \\
\hline & & 0.083 & 7 & 89.52 \\
\hline & & 0.076 & 9 & 90.40 \\
\hline & & 0.1 & 11 & 87.37 \\
\hline \multirow[t]{5}{*}{$\mathrm{Hg}$} & 0.911 & 0.172 & 3 & 81.11 \\
\hline & & 0.151 & 5 & 83.42 \\
\hline & & 0.109 & 7 & 88.03 \\
\hline & & 0.098 & 9 & 89.24 \\
\hline & & 0.137 & 11 & 84.96 \\
\hline
\end{tabular}


Table. 4: Metal removal efficiency of $\mathrm{KL}_{1}$ ligand with $5 \mathrm{mg}$ metals

\begin{tabular}{lcccc}
\hline Metal & $\begin{array}{c}\text { Initial concentration } \\
(\mathrm{ppm})\end{array}$ & $\begin{array}{c}\text { Remaining concentration in } \\
\text { aqueous solution }(\mathrm{ppm})\end{array}$ & $\begin{array}{c}\mathrm{pH} \\
\text { Removal } \\
\text { efficiency (\%) }\end{array}$ \\
\hline $\mathrm{Cd}$ & 0.911 & 0.137 & 3 & 84.96 \\
& & 0.129 & 5 & 85.83 \\
& & 0.122 & 7 & 86.60 \\
$\mathrm{Zn}$ & 0.879 & 0.131 & 9 & 85.62 \\
& & 0.139 & 11 & 84.74 \\
& & 0.156 & 3 & 82.25 \\
& & 0.151 & 5 & 82.82 \\
$\mathrm{Cu}$ & 0.144 & 7 & 83.61 \\
& 0.829 & 0.122 & 9 & 86.12 \\
& & 0.130 & 11 & 85.21 \\
& & 0.107 & 3 & 87.09 \\
$\mathrm{Hg}$ & 0.096 & 5 & 88.41 \\
& & 0.091 & 7 & 89.02 \\
& & 0.085 & 9 & 89.74 \\
& & 0.099 & 11 & 88.05 \\
& & 0.131 & 3 & 86.03 \\
& & 0.127 & 5 & 86.46 \\
& & 0.113 & 7 & 86.24 \\
& & 0.129 & 9 & 87.95 \\
& & 0.135 & 11 & 85.60 \\
\hline
\end{tabular}

Table. 5: Metal removal efficiency of $\mathrm{KL}_{2}$ ligand with 0.05 mg metals

\begin{tabular}{lcccc}
\hline Metal & $\begin{array}{c}\text { Initial concentration } \\
(\mathrm{ppm})\end{array}$ & $\begin{array}{c}\text { Remaining concentration in } \\
\text { aqueous solution }(\mathrm{ppm})\end{array}$ & $\begin{array}{c}\mathrm{pH} \\
\text { Removal } \\
\text { efficiency }(\%)\end{array}$ \\
\hline $\mathrm{Cd}$ & 0.921 & 0.087 & 3 & 90.55 \\
& & 0.081 & 5 & 91.20 \\
& & 0.069 & 7 & 92.50 \\
$\mathrm{Zn}$ & 0.759 & 0.073 & 9 & 92.07 \\
& & 0.085 & 11 & 90.77 \\
& & 0.098 & 3 & 87.08 \\
& & 0.095 & 5 & 87.84 \\
$\mathrm{Cu}$ & 0.089 & 7 & 88.27 \\
& 0.880 & 0.068 & 9 & 91.04 \\
& & 0.079 & 11 & 89.59 \\
& & 0.071 & 3 & 91.93 \\
$\mathrm{Hg}$ & & 0.065 & 5 & 92.61 \\
& & 0.055 & 7 & 93.75 \\
& 0.841 & 0.049 & 9 & 94.43 \\
& & 0.060 & 11 & 93.18 \\
& & 0.068 & 3 & 91.91 \\
& & 0.063 & 5 & 92.50 \\
& & 0.059 & 7 & 92.98 \\
& & 0.050 & 9 & 94.05 \\
& & 0.057 & 11 & 93.22 \\
\hline
\end{tabular}


Table. 6: Metal removal efficiency of $\mathrm{KL}_{2}$ ligand with $5 \mathrm{mg}$ metals

Metal

Fig. 3. Effect of pH on the \% recovery of heavy metal ions $(0.05 \mathrm{mg})$ with $\mathrm{KL}_{1}$ ligand

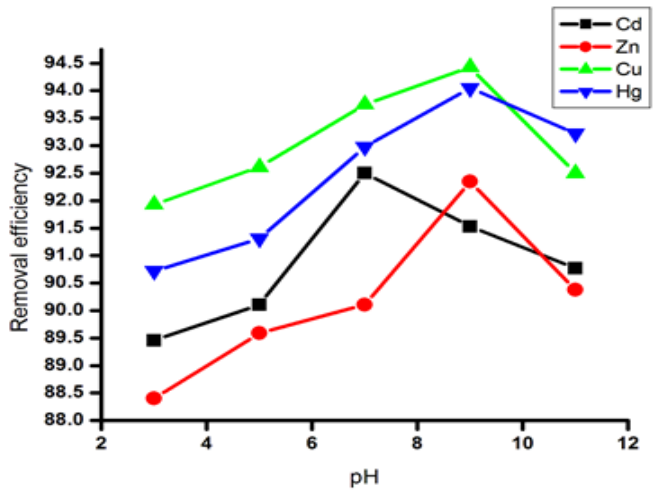

Fig. 5. Effect of pH on the \% recovery of heavy metal ions $(0.05 \mathrm{mg})$ with $\mathrm{KL}_{2}$ ligand

\begin{tabular}{ccc}
$\begin{array}{c}\text { Remaining concentration in } \\
\text { aqueous solution (ppm) }\end{array}$ & $\mathrm{pH}$ & $\begin{array}{c}\text { Removal } \\
\text { efficiency(\%) }\end{array}$ \\
\hline 0.099 & 3 & 89.74 \\
0.086 & 5 & 91.08 \\
0.081 & 7 & 91.60 \\
0.089 & 9 & 90.77 \\
0.097 & 11 & 89.94 \\
0.104 & 3 & 87.72 \\
0.100 & 5 & 88.19 \\
0.099 & 7 & 88.31 \\
0.085 & 9 & 89.96 \\
0.098 & 11 & 88.42 \\
0.098 & 3 & 89.90 \\
0.091 & 5 & 90.62 \\
0.085 & 7 & 91.24 \\
0.072 & 9 & 92.58 \\
0.081 & 11 & 91.65 \\
0.087 & 3 & 90.41 \\
0.081 & 5 & 91.07 \\
0.069 & 7 & 92.40 \\
0.065 & 9 & 92.84 \\
0.074 & 11 & 91.85
\end{tabular}

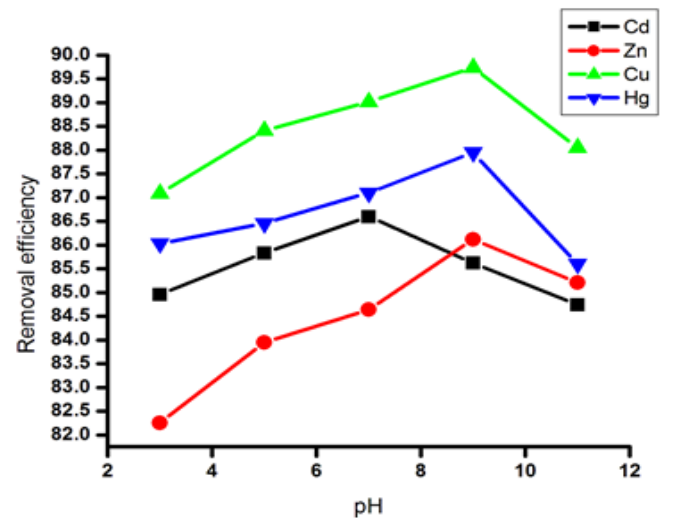

Fig. 4. Effect of pH on the \% recovery of heavy metal ions $(5 \mathrm{mg})$ with $\mathrm{KL}_{1}$ ligand

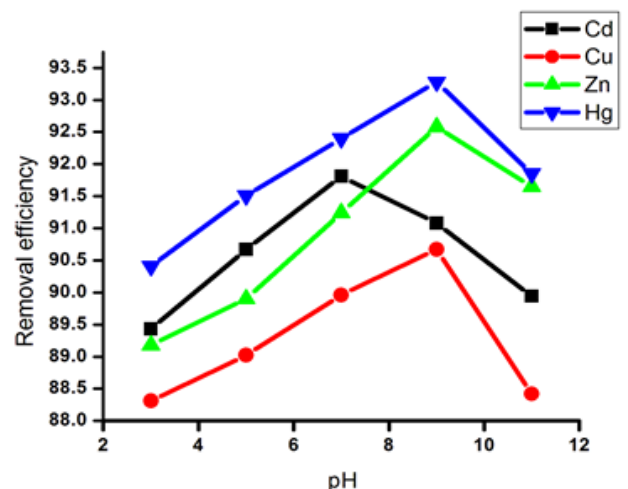

Fig. 6. Effect of pH on the \% recovery of heavy metal ions $\left(5 \mathrm{mg}\right.$ ) with $\mathrm{KL}_{2}$ ligand 


\section{Metal removal capacity of ligands}

The method involved for trapping metals from its solution using different dithiocarbamate ligands $\left(\mathrm{KL}_{1}\right.$ and $\left.\mathrm{KL}_{2}\right)$ were study using $\mathrm{AAS}$ at different $\mathrm{pH}$ values. The result obtained by AAS measurement shown in table 3-6 indicate that removal efficiency of all the heavy metals are varies with varying the $\mathrm{pH}$. The optimal removal efficiency was found $87.20 \%$ in the case of cadmium metal (0.05 mg) with ligand $\mathrm{KL}_{1}$ at $\mathrm{pH} 7$; but when water sample were spiking with $5 \mathrm{mg}$ of metal with same ligand, the removal efficiency are decrease i.e. $86.60 \%$ this is because when the concentration of metal reaches at 100 times the stability of ligandmetal complex are decrease. Whereas in basic and acidic medium lower efficiency of $\mathrm{KL}_{1}$ ligand with cadmium metal was observed. Likewise the removal efficiency was observed at maximum 89.58 $\%$ at highly basic medium for zinc metal and it was $90.40 \%$ and $89.24 \%$ observed for copper and mercury at basic medium. Whereas the highest removal efficiency $92.50 \%$ was noted in the case of cadmium metal at $\mathrm{pH} 7$ with $0.05 \mathrm{mg}$ of metal with ligand $\mathrm{KL}_{2}$ while when the water sample spike with $5 \mathrm{mg}$ of the metal the efficiency decrease 91.60 $\%$, this indicate that when the water sample is contaminated maximum with cadmium metal the removal efficiency decrease. Same observation was observed for another heavy metal ions. So, $\mathrm{pH}$ values and concentration of metal plays an important role in the removing efficiency for the heavy metal ions and it was changes upon changing the $\mathrm{pH}$ and metal concentration for the same ligand. The graphical representation of $\mathrm{pH}$ vs \% removal efficiency was shown in Figure. 3-6.

Finally, it was observed that the ligand $\mathrm{KL}_{2}$ have higher removal efficiency in comparison to the ligand $\mathrm{KL}_{1}$, this is because the $\mathrm{N}$-substituted dithiocarbamate metal complexes shows higher stability than the $\mathrm{C}$-substituted dithiolate metal complexes due to presence of free lone pair on the nitrogen which upon delocalization the partial $\mathrm{C}-\mathrm{N}$ double bond character after the complexation, indicating the removal efficiency primarily depends on the types of ligands are used.

\section{CONCLUSION}

All the complexes were found in 98.72$99.21 \%$ of yields by facile metathetical reactions between metals and the potassium salt of the ligands $\left(\mathrm{KL}_{1}\right.$ and $\left.\mathrm{KL}_{2}\right)$ in a 1:2 molar ratio in 80:20 v/N methanol: water solution. The complexes are stable at r.t. and melt/ decompose in the $135-200^{\circ} \mathrm{C}$ temperature range. All the ligands and complexes have been analyzed by different spectroscopy techniques like IR, ${ }^{1} \mathrm{H}$ and ${ }^{13} \mathrm{C}$ NMR and UV-Vis Spectroscopy.The ultraviolet spectroscopy clearly indicate that the complexes have the formula $\mathrm{ML}_{2}$. The dichloromethane extraction of the heavy metal complexes showed that it was quantitatively pass from the water phase to the small volume of the organic phase and were successfully separated into organic phase. It was observed that the $\mathrm{N}$-substituted dithiocarbamate ligand was more effective in removing the trace heavy metal ions from water sample solution compared to the C-substituted dithiocarbamate ligand at the same $\mathrm{pH}$ value.

\section{ACKNOWLEDGEMENT}

We gratefully acknowledge the University Grant Commission (UGC), New Delhi for financial assistance in the form of Senior Research Fellow Ref. No: 22/12/2013 (II) EU-V. Authors are thankful to Mr. Himanshu, Department of Metallurgical Engineering, IIT, B.H.U. Varanasi for the FAAS measurement.

\section{REFERENCES}

1. Hogarth, G. Prog. Inorg.chem., 2005, 53, 71-561.

2. Fujii, S.; Yoshimura, T. Coord. Chem. Rev., 2000, 198, 89-99.

3. Cooksona, J.; Beer, P. D.; Dalton Trans., 2007, 15, 1459-1472.

4. Marcheselli, L.; Preti, C.; Tagliazucchi, M.;
Cherchi, V.; Sindellari, L.; Furlani, A.; Papaioannou, A.; Scarcia, V. Eur. J. Med.Chem., 1993, 28, 347-352.

5. Peter, J. N.; Andreas, W. E.; Jaap, G. H.; Sander, R. J.; Jan, R.; Evert, J. B. J. Am. Chem. Soc., 1999,121, 163-168. 
6. Becker, R.; Knorr, A.; Lubr.Sci., 1996, 8, 95-117.

7. Lishant,H-Van; Schwack, W. J. AOAC Int., 2000, 83,720-727.

8. Dogheim, S.M.; alla, S.A.G.; El-Marsafy, A.M.; Fahmy, S.; J. AOAC Int., 1999, 82, 948-955.

9. Malik, A. K.; Faubel, W. Pestic Sci., 1999, 55, 965-970.

10. Humeres, E.; Debacher, N.A.; de, M.M.; Sierra, S.; J. Org. Chem., 1999, 64, 1807-1813.

11. Rajput, G.;Singh, V.;Singh, S. K.;Prasad, L. B.; Drew, M. G. B.; Singh, N.Eur. J. Inorg. Chem., 2012, 3885-3891.

12. Rajput, G.;Singh, V.; Gupta, A. N.; Yadav, M. K.; Kumar, V.; Singh, Kumar, S.; Prasad, A.; Drew, M. G. B.; Singh, N. Cryst. Eng. Comm., 2013, 15, 4676-4683.

13. Zahra, A.; Hashmi, M.Z.; Malik, R.N.; Ahmed, Z. Sci.Total Environ, .2014, 470, 925-933.

14. Ali, H.; Khan, E.; Sujad, M.A. Chemosphere., 2013, 91, 869-881.

15. Zhao, G.; Li, J.; Ren, X.; Chen, C.; Wang, X. Environ. Sci. Technol., 2011, 45,10454-10462.

16. Plum, L.M.; Rink, L.; Haase, H. Int. J. Environ. Res. Public Health., 2010, 7, 1342-1365.

17. Juang, R.S.; Shiau, R.C.; J. Membrane Sci.,
2000, 765, 159-167.

18. Amuda, O.S.; Amoo,I.A.; Ajayi, O.O. J. Hazard. Mat., 2006, 129, 69-72.

19. Dauvalter,V.A. Water Res., 1998, 25, 451-457.

20. Baron,J.; Letret,M.;Astruc,M.Environ. Technol., 1990, 11, 151-162.

21. Jensen, K.A.; Henriksen, L.; Acta. Chem. Scand., 1968, 22, 1107-1128.

22. Manar, K. K.; Yadav, M. K.; Anamika; Drew, M. G.B.; Singh, N.Polyhedron., 2016, 117, 592-599.

23. Gupta, A. N.; Singh, V.; Kumar V.; Rajput, A.; Singh L.; Drew,M. G.B.; Singh,N.Inorganica Chimica Acta., 2013, 408, 145-151.

24. Awang, N.; Baba, I.; Yamin, B.M.; Othman, M.S.; Kamaludin, Amer. J. Appl. Sci., 2011, 8, 310-317.

25. Mangsup, L.; Siripalsarnpipat, S.;Chaichit,N. Anal.Sci., 2003,19, 1345-1353.

26. Khalid, J.; AL-Adilee; Ahmed, A. K.; Ali, M.T.; J.Molecular structure., 2016, 1108, 378-397.

27. Awang, N.; Baba, I.; Yamin, B. M.; Othman, M. S.; Kamaludin, N. F. Amer. J. Appl. Sci., 2011, 8, 310-317. 